\title{
Analyses of Dynamics in Dairy Products and Identification of Lactic Acid Bacteria Population by Molecular Methods
}

\author{
Aytul Sofu*
}

Department of Chemical Engineering, Suleyman Demirel University, 32260 Isparta, Turkey

\section{A R T I C L E I N F O}

\section{Review articles}

Received 13 April 2016

Accepted 15 December 2016

Keywords:

Lactic acid bacteria (LAB)

16 S rRNA

Dairy products

Molecular method

Identification

${ }^{*}$ Corresponding Author:

E-mail: aytulsofu@sdu.edu.tr

\begin{abstract}
A B S T R A C T
$\overline{\text { Lactic acid bacteria (LAB) with different ecological niches are widely seen in fermented }}$ meat, vegetables, dairy products and cereals as well as in fermented beverages. Lactic acid bacteria are the most important group of bacteria in dairy industry due to their probiotic characteristics and fermentation agents as starter culture. In the taxonomy of the lactic acid bacteria; by means of rep-PCR, which is the analysis of repetitive sequences that are based on 16S ribosomal RNA (rRNA) gene sequence, it is possible to conduct structural microbial community analyses such as Restriction Fragment Length Polymorphism (RFLP) analysis of DNA fragments of different sizes cut with enzymes, Random Amplified Polymorphic DNA (RAPD) polymorphic DNA amplified randomly at low temperatures and Amplified Fragment-Length Polymorphism (AFLP)-PCR of cut genomic DNA. Besides, in the recent years, non-culture-based molecular methods such as Pulse Field Gel Electrophoresis (PFGE), Denaturing Gradient Gel Electrophoresis (DGGE), Thermal Gradient Gel Electrophoresis (TGGE), and Fluorescence In-situ Hybridization (FISH) have replaced classical methods once used for the identification of LAB. Identification of lactic acid bacteria culture independent regardless of the method will be one of the most important methods used in the future pyrosequencing as a Next Generation Sequencing (NGS) techniques. This paper reviews molecular-method based studies conducted on the identification of LAB species in dairy products.
\end{abstract}

Türk Tarım - Gıda Bilim ve Teknoloji Dergisi, 5(1): 6-13, 2017

\section{Süt Ürünlerindeki Laktik Asit Bakterilerinin Moleküler Yöntemlerle Dinamiklerinin Analizi ve Populasyonlarının Tanımlanması}

\section{A K A L E B İ L G İ S İ}

\section{Derleme makale}

Geliş 13 Nisan 2016

Kabul 15 Aralık 2016

Çevrimiçi baskı, ISSN: 2148-127X

Anahtar Kelimeler:

Laktik asit bakterileri (LAB)

16 S rRNA

Süt ürünleri

Moleküler metot

Tanımlama

${ }^{*}$ Sorumlu Yazar:

E-mail: aytulsofu@sdu.edu.tr

\section{Ö Z E T}

Farklı ekolojik nişlere sahip Laktik asit bakterileri (LAB) yaygın olarak fermente et, sebze, süt ürünleri ve tahıllar yanı sıra mayalanmış içkilerde de bulunmaktadır. LAB'lar probiyotik özelliklerinden dolayı starter kültür olarak süt endüstrisinde kullanılan bakterilerin en önemli grubudur. LAB'ların taksonomik incelemelerinde; 16S ribozomal RNA (rRNA) gen dizilerinin analizine dayalı rep-PCR analizi, farklı boyutlarda enzimler ile kesilmiş DNA fragmanlarının analizi (RFLP), rastgele çoğaltılmış polimorfik DNA analizi (RAPD), düşük sıcaklıklarda rastgele çoğaltılmış ve DNA'nın çoğaltılmış parçauzunluk polimorfizm analizi (AFLP)-PCR kullanılmaktadır. Ayrıca LAB'ların tanımlanmasında kullanılan kültür bağımsız yöntemler, darbe etkili alan jel elektroforez (PFGE), denatüre gradyan jel elektroforez (DGGE), termal gradyan jel elektroforez (DGGE) ve floresan in situ hibridizasyon (FISH) yöntemleri bulunmaktadır. Bunun yanı sıra, son yıllarda yeni nesil dizi (NGS) teknikleri ve Pirosekanslama gelecekte kullanılan en önemli yöntemlerden biri olacaktır. $\mathrm{Bu}$ yazıda süt ürünlerinde $\mathrm{LAB}$ türlerinin belirlenmesi için moleküler yöntemleri kullanan çalışmaları kapsamaktadır. 


\section{Introduction}

Most LAB can be isolated from natural environments such as humans, animals and plants. They are adapted to a specific environment and they are widely seen in fermented meat, vegetables, dairy products and cereals as well as in fermented beverages (Holzapfel et al., 2001; Temmerman et al., 2004). They are widely used in fermented dairy products. Because of they are naturally exist in cheeses made by traditional methods, they constitute the basic flora during maturation. They give specific sensory and structural properties to products. In addition, due to the antimicrobial substances they produce, they are therapeutic and they support health. Lactic acid bacteria flora of dairy products produced with traditional methods have recently become the subject of many researches (Temmerman et al., 2004). In these studies, it is aimed to maintain the lactic acid bacteria diversity in the products and to transfer those that were important from technological and health aspects into the industrial scale. To achieve this goal, the use of appropriate identification methods as well as an accurate identification of the bacteria is required (Temmerman et al., 2004).

In the traditional identification of $\mathrm{LAB}$, in addition to the use of API test kits, biochemical tests that were based on carbohydrate digestion and peculiar enzymatic activities had been used. However, the bacteria in different environmental conditions try to fit themselves to ambient conditions. Bacteria which adapt to the different ambient conditions of their isolated environments can sometimes react in these tests. This situation causes them to be identified as a new species or not to be identified. Therefore, it has been found that species with different genotypic characteristics displayed similar phenotypic characteristics and it has been understood that it was not safe to identify bacteria by this method relying on the fact that they had similar nutritional requirements (McCartney, 2002; Saarela et al., 2000). As a result, genotypic identification methods began to be used to obtain a better classification and distinction among the species.

Recently, faster and safer methods that will construct profiles of microbial communities from many environments have been developed (Ward et al., 1990). Most of these methods are based not only on the identification of microorganisms, but they are based also on the analysis of these microorganisms' nucleic acids (Ampe et al., 1999; ben Omar and Ampe, 2000).

For microbial identification and classification purposes, molecular techniques can be classified as metabolic based methods, protein based methods, fatty acid based methods and nucleic acid based methods. REP-PCR made it possible to conduct structural microbial community analyses such as RFLP analysis of DNA fragments of different size cuts with enzymes, RAPD polymorphic DNA amplified randomly at low temperatures, and AFLP PCR of cut genomic DNA. Besides, in the recent years, non culture based molecular methods such as PFGE, DGGE, TGGE, FISH and NGS have replaced classical methods once used for the identification of LAB (Figure 1).

\section{Nucleic Acid Based Techniques}

Chemistry of nucleic acids and the studies conducted to describe the structural characteristics constitute the basis of molecular identification methods. Enzymes are used to replicate the target DNA and a copy of DNA can be identified theoretically. The fact that Mullis (1990) applied thermostable Taq DNA polymerase isolated from Thermus aquaticus in chain reaction (PCR) technique with success allowed for the replication of specific DNA sequences in vitro conditions. Analysis of $16 \mathrm{~S}$ rRNA sequences revealed the existence of this molecule on variable zones and highly protected zones that reflect the different degrees of functional pressure on different parts of the molecule during evolution. In fact, preserved zones are suitable for the secondary structures which are active in the obtainment of a functional ribosome. Variable zones are useful in the comparison of closely related organisms, whereas protected zones are useful in the grouping of distant relatives. Comparison of oligonucleotide sequence in $16 \mathrm{~S}$ RNA is used in bacterium phylogenetics and systematic studies. These molecules can assimilate the molecular chronometers which show the evolution steps of the bacteria. 16S rRNA molecules are used to benefit from the short term comparisons to find out the common origins of the bacteria and to determine the direction, importance and the speed of the evolution. Amplification and identification of target DNA/RNA sequences were followed by PCR based efforts intended to develop more sensitive and specific methods (Böttger, 1989; Giovannoni et al., 1990; Ward et al., 1990; Muyzer et al., 1993; Ludwig and Schleifer, 1994; Amann et al., 1995; Head et al., 1998; Harmsen and Karch, 2004).

\section{Culture-Based Genotypic Identification Techniques}

\section{Repetitive Extragenic Palindromic (REP-PCR)}

REP-PCR, are the repetitive protected sequences in regions between genes (Repetitive extragenic palindromic), and when proliferation of these sequences is done with the universal primers DNA fragments (amplicon) belonging to each sample can be produced in various sizes. In this way, subspecies and races can be distinguished from each other. As for the rDNA genes, they are highly protected in a species-specific manner. Therefore, species/subspecies specific DNA sections can be produced with primers particularly designed for these genes and the intermediate regions there of (ITS-PCR internally transcribed spacers). rRNA genes are an appropriate choice as a first step in identifying especially a totally unknown organism. The other important target sequences are widely seen and protected in repetitive extragenic palindromic (REP), which are bacterium genomes and repetitive palindromic sequences situated between the genes. REP-PCR fingerprint technique which is carried out by using (GTG) $\left.)_{5}-\mathrm{PCR}\right)$, is a rapid, reliable and easily- applicable method that allow for distinguishing of LAB species, subspecies and strains in the food fermentation industry (Gevers et al., 2001).

In the REP-PCR applications, LAB dynamics was investigated in the cheddar cheese during the maturation 
stage by using with REP and ERIC (enterobacterial repetitive intergenic consensus) primer sets (Dasen et al., 2003). A total of 380 Lactobacillus species have been identified. Olive and Bean, (1999) isolated LAB from probiotic foods by using REP-PCR technique. Mohammed et al. (2009) isolated 170 species from the traditional dairy products and raw milk samples in delta region by applying REP-PCR fingerprint method. The obtained results revealed that the following species were dominant in dairy products in Egypt: $L b$. delbrueckii subsp. lactis, Lb. fermentum, Enterococcus faecium Lb. delbrueckii subsp. bulgaricus, Lb. paracasei subsp. paracasei, Lb. plantarum and Lc. lactis subsp. lactis.

\section{Restriction Fragment Length Polymorphism (RFLP)}

RFLP technique recognizes a single nucleic acid base change in a specific region cut by enzymes. A variation in base array in recognition region can be the reason of polymorphism between different genotypes. However, this polymorphism arises more frequently from segment insertion or deletion between two cutting regions which are recognized by cutting enzymes. At the same time, amplicons obtained as a result of the PCR reactions or the entire DNA is disintegrated by restriction enzymes. This technique is defined as RFLP and it is the prototype of DNA fingerprinting methods used for the identification of the isolates at the intra-species diversity.

It is used for the identification of intra-species bacteria in dairy products. In the previous studies; Giraffa et al. (2003) by means of RFLP analysis, determined proteinencoded genes $(\beta$-galactosidase, lactose permease and proline dipeptidase) of 35 molecular types of $L b$. delbrueckii subsp. lactis and Lb. delbrueckii subsp. bulgarius which were taken from dairy products and used as starter cultures. Homofermentative LAB was isolated from pot cheese, a traditional cheese made from cow and goat's milk. This study 661 microbial isolates were taken from a total of 17 cheese samples. In the study, identifications have been made by using phenotypic and molecular methods. It was found that only 107 isolates were homo-fermentative. Lc. lactis subsp. lactis of 54, Enterococcus faecium of 21, Ec. faecalis of 3, Ec. durans of 2, Ec. sp., of 10, Lb. paracasei subsp. paracasei of 15, and $L b$. casei of 2 were determined by PCR-RFLP based molecular identification by using ITS (internally transcribed spacer) gene region.

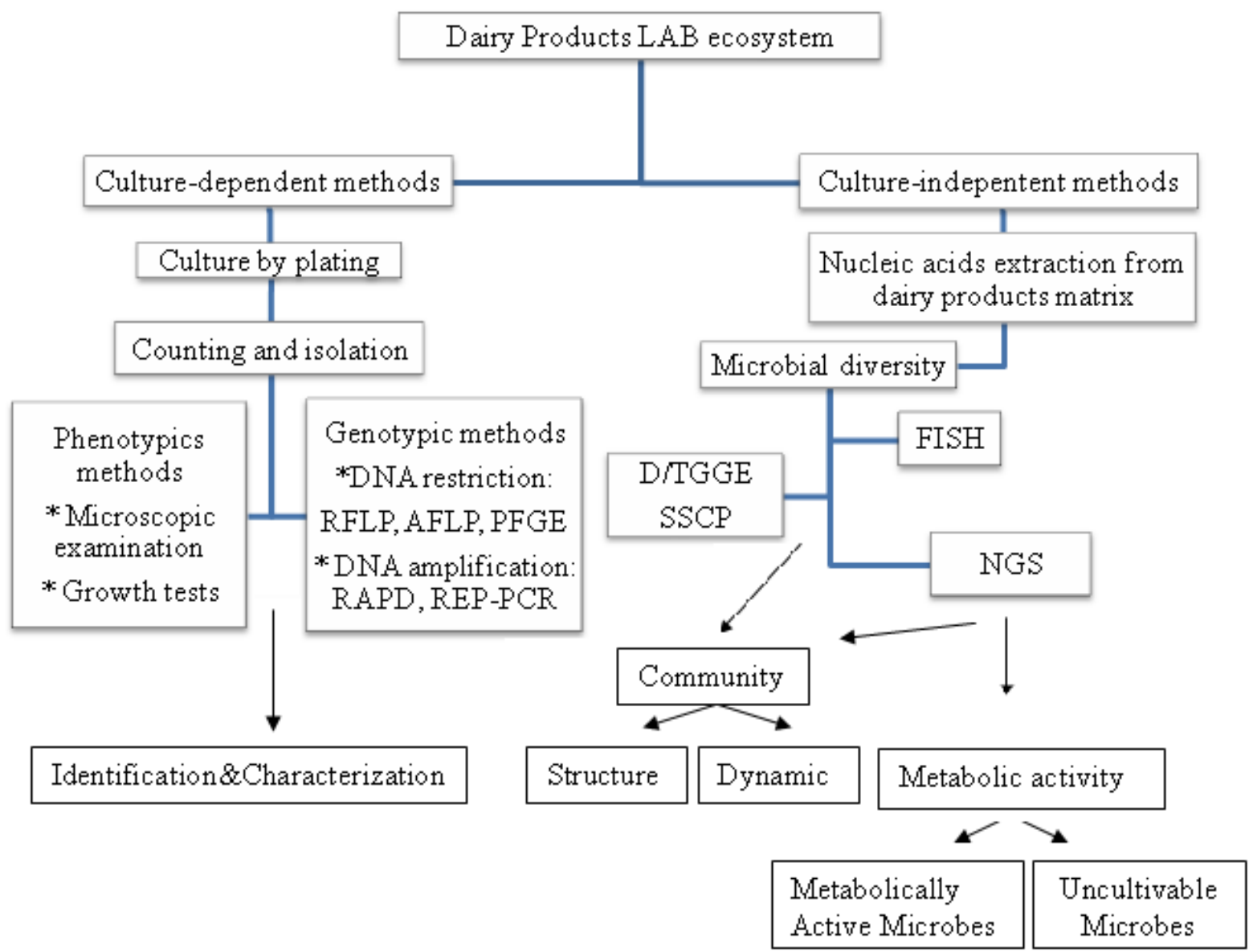

Figure 1 Flow diagram of the culture-dependent and culture-independent methods to study the community structure and activitiy of dairy products microbiota. RFLP restriction fragment length polymorphism, AFLP amplified fragmentlength polymorphism, $P F G E$ pulsed-field gel electrophoresis, $R A P D$ Random Amplified Polymorphic DNA, REP-PCR Repetitive extragenic palindromic, FISH Fluorescence in situ hybridization, $D G G E$ denaturing gradient gel electrophoresis, TGGE temperature gradient gel electrophoresis, SSCP single strand conformation polymorphism, NGS Next-generation sequencing 


\section{Random Amplified Polymorphic DNA (RAPD)}

Polymorphic DNA amplified randomly at low temperatures: Another approach to the genome was the RAPD markers obtained as a result of random connections. In RAPD analysis, markers which vary among races are chosen and sequence analysis is conducted. These markers can be directly used in the identification species.

RAPD analysis was of a fingerprint of short DNA fragments electrophoretically separating replicated in randomly selected primers and low temperature conditions. RAPD technique has been used for the isolation of thermophilic streptococci and Lactobacillus from the following types of cheese: Italian, French and Spanish cheeses and cheeses made from raw cattle milk such a Mozzarella (Moschetti et al., 1998; Morea et al., 1998; De Candia et al., 2007); Parmigiano Reggiano \& Grana Padano cheeses (Cocconcelli et al., 1997); Beamfort, Comte, and Manchego cheeses (Bouton et al., 2002; Sánchez et al., 2006). Baruzzi et al. (2000) used the technique to isolate $L b$. kefir and $L b$. paracasei species from Ricotta forte cheese; Albenzio et al. (2001) used the technique to isolate $L b$. plantarum species from Canestrato Pugliese cheese. Oneca et al. (2003) used the technique on Roncal cheese. RADP technique has been used in the isolation of lactococcal species from the following cheese types: RDO Camembert cheese (Corroler et al., 1998; Desmasures et al., 1998), Mozzarella cheese (Morea et al., 1999), Toma Piemontese cheese (Fortina et al., 2003), Raschera and Castelmagno PDO cheese (Dolci et al., 2008).

The species isolated from industrial dairy products and Italian cheeses were found as Lb. casei / paracasei, Lb. plantarum, Lb. rhamnosus, Lb. helveticus, $L b$. delbrueckii, Lb. fermentum, Lb. brevis, Ec. faecium, Ec. faecalis, Streptococcus thermophilus and Lc. lactis, according to the information gathered from RAPD-PCR fingerprint library unit (Rossetti et al., 2005).

Amplified Fragment-Length Polymorphism (AFLP)PCR of cut genomic DNA: AFLP technique consists of the following: cutting of DNA by restriction enzymes (EcoRI / Mse I) and combination of restriction fragments by means of a suitable DNA ligase by using 2 adapters. Then pre-amplification of restriction fragments by a primer that is suitable for these combined adapters and the real amplification of these fragments and the primers; and the execution of polyacrylamide gel electrophoresis (PAGE) (Janssen et al., 1996). Originally, AFLP technique has been used in the cultivation of plants. AFLP technique was found to be a useful fingerprint technique in the differentiation of bacteria species and strains.

AFLP is the most commonly used technique in epidemiological studies and is again the most commonly used technique to separate the infecting forces of food borne pathogens. In their research, Giraffa and Neviani (2000) found that the species of $L b$. pentosus, $L b$. plantarum and $L b$. pseudoplantarum were the most similar to each other among the LAB species on the species level.

Foschino et al. (2008) stated that they found 32 genotypic differences among $L$. garvieae species from Italian dairy products by using AFLP.
Dellaglio et al. (2005) identified a new sub-type, $L b$. delbrueckii subsp. indicus subsp. Nov. $\left(\mathrm{NCC} 725^{\mathrm{T}}\right)$, by using AFLP and RAPD-PCR fingerprinting technique based on the phylogenetic analysis of $16 \mathrm{~S}$ rRNA gene sequence and sequence analysis of the two code genes recA and $h s p 60$ of $L b$. delbrueckii isolated from Indian dairy products.

\section{Pulsed-Field Gel Electrophoresis (PFGE)}

PFGE is regarded as a gold standard of molecular typing methods. In this method, bacteria produced in a broth or a solid medium are poured into little molds after mixing with agarose with low melting temperature. Bacterial cells mixed with agarose are disintegrated (insitu-lysis) with the help of detergents and enzymes and then the DNA isolation is performed. Because intact DNA is required in PFGE, the traditional isolation which may cause breaks in the DNA is not suitable for this method. Following the lysis process, agarose molds are washed or dialyzed thoroughly so as to remove the contaminants such as proteins and carbohydrates. Intact chromosomal DNA is kept in the agarose gel. Bacterial DNA in the agarose is cut (in situ-digestion) with a restriction enzyme (RE) so as to result in bigger and less number of fragments. Later, molds that contain cut DNA pieces are placed into the appropriate slots in the gel on which electrophoresis will be applied and they are subjected to the electric current whose direction is altered regularly. Such an electric current allows for the clear distinguishing of 10-800 kilobase DNA segments. PFGE is used to separate large DNA fragments resulting from the restriction disintegration performed with rare-cutting enzymes. Most important aspect of PFGE is the extraction of intact chromosomal DNA. In addition to this, it has extraordinarily separated the large DNA fragments showing the entire genome of subspecies of many different microorganisms since the invention of PFGE analysis (McCartney, 2002). Numerous Lb. johnsonii subspecies have been analyzed by the PFGE method.

By using PFGE technique the following distinctions have been made among probiotic bacteria species: Bifidobacterium longum and B. animalis (Roy et al., 1996), Lb. casei and Lb. rhamnosus (Tynkkynen et al., 1999), Lb. acidophilus (Roy et al., 2000), Lb. helveticus (Lortal et al., 1997), and Lb. johnsonii (Ventura and Zink, 2002).

\section{Non-Culture-Based Molecular Methods}

In recent years, non-culture-based methods have become powerful tools for the determination of microbial diversity in dairy products. They are PCR-based molecular methods used to identify bacterial populations that constitute communities. Non-culture-based methods are used for controlling fingerprints of microbial populations and they allow for inter-population relations and comparisons (Duineveld et al. 1998; Ampe \& Miambi 2000). They contribute to creation of the microbial ecology index. They are new approaches that directly determine the genetic diversity of complex microbial populations. 
Denaturing Gradient Gel Electrophoresis (DGGE)

DGGE method, DNA parts are of the same length but they can be separated according to different DNA base pair sequences. Separation in DGGE is dependant on the electrophoretic mobility of the DNA molecule partially melted in the polyacrylamide gel. This mobility of DNA molecules is lower when compared to the full spiral form. The melting of parts occurs over the frequently mentioned melting regions. When the melting zone with the lowest melting temperature reaches this temperature at a certain position in DGGE gel, a transition state occurs where partially melted molecules and spiral form exist together. Thus the movement of molecules is practically comes to an end. Studies have been conducted to isolate Bifidobacterium (Rigottier-Gois et al., 2003), Lactobacillus, Pediococcus, Leuconostoc and Weisella (Walter et al., 2001; Heilig et al., 2002) species through the use of LAB specific PCR primers. In another study, the microbial composition determined in probiotic products, 2 identification ladders including 8 Lactobacillus and 7 Bifidobacterium species were used (Fasoli et al., 2003). Additional identification techniques were not required although some probiotic LAB species could not be distinguished (Temmerman et al., 2004) Ercolini et al. (2003) identified the microbial community in Stilton cheese by using the PCR-DGGE along with $16 \mathrm{~S}$ ribosomal DNA analysis. They extracted DNA templates from the cheese by means of PCR experiments. V3 and V4-V5 regions of the $16 \mathrm{~S}$ genes were analyzed and $L c$. lactis, Ec. faecalis, Lb. plantarum, Lb. curvatus, Lc. mesenteroides, Staphylococcus equorum, and Staphylococcus sp. were identified as the nearest ones in the DGGE fragment sequence.

Ercolini et al. (2003) identified microbial changes observed during the production of traditional water buffalo mozzarella cheese by PCR-DGGE. The total microbial DNA of mesophilic and thermophilic LAB was extracted directly from dairy products as mass colonies and PCR-DGGE were used. Florez and Mayo (2006) compared the results of products obtained by traditional culture methods with the results of non-culture products. $\mathrm{V} 3$ region of the bacterial $16 \mathrm{~S}$ rRNA gene and the D1 region of eukaryotic 26s rRNA gene taken from the microbial population in the milk of cheese and in the traditional blue veined Spanish cheese made by using rennet extract were analyzed and aimed to be identified. El-Baradei et al. (2007) used PCR-TTGE and PCRDGGE to identify the bacterial diversity of the traditional Egyptian soft cheese Domiati. Dominant LAB species are the following: Lc. mesenteroides, Lc. garvieae, Aerococcus viridans, $L b$. versmoldensis, Pediococcus inopinatus, and Lc. lactis. Coagulase negative staphylococci that include common non-LAB species are the following: Vibrio spp., Kocuria rhizophila, Kocuria kristina, Kocuria halotolerans, Arthrobacter spp. / Brachybacterium tyrofermentans. Cocolin et al. (2004) identified Clostridium spp in Late Blowing cheese samples by using PCR- DGGE method. They determined Clostridium spp. and different types of lactic acid bacteria under experimental conditions by PCR amplification and difference of DGGE.
Coppola et al. (2001) identified microbial diversity in Pasta Filata cheeses in different immature forms that were produced for traditional and commercial purposes by using PCR-DGGE, a non-culture based method.

\section{Temperature Gradient Gel Electrophoresis (TGGE)}

It is the monitoring of the changes occurring on polyacrylamide gel that due to the changes in the structure of DNA that occur by the effect of temperature. TGGE not only separates molecules but also provides information about melting behavior and stability. The TGGE system operates similar to DGGE system on the other hand, while temperature gradient is used in TGGE, a gradient structure is built by solutions in DGGE. Both methods are used to reveal the genetic diversity of microorganisms in different habitats. DGGE method and TGGE method both work on the basis of the same principle. Ogier et al. (2002) who have conducted studies on various dairy products and cheeses, and Coppola et al. (2001) who have conducted studies on Mozzarella cheese revealed the profiles of the lactic acid bacteria in the by using TGGE method.

\section{Single Strand Conformation Polymorphism (SSCP)}

SSCP is a method based on the facts that various conformations are formed as each chain is folded and twisted in different forms as a result of intra-molecular interactions of single chained DNAs and that these conformations move at different speed on the polyacrylamide gel. The presence of mutation is indicated by the difference between the normal and the examined specimens. Although point mutations can be identified with certainty by DNA sequence analysis; as the DNA fragment to be scanned grows, duration of diagnosis and analysis costs increase. In order to prevent this, the gene containing the mutation is amplified in short DNA fragments (200 bp) and scanned by the SSCP method, and finally the fragment containing the mutation is determined. Thus, analysis duration and costs are reduced as only the fragment containing the mutation is analyzed instead of the entire big gene. The main goal here is to determine the region of mutation.

Various bacteria populations and metabolic activities are introduced by means of SSCP method in the study conducted by Duthoit et al. (2003) on Salers cheeses, the traditional cheese of France, and in the study conducted by Callon et al. (2004) on AOC Saler cheese. Delbes and Montel (2005) used PCR-SSCP method in the identification of staphylococcus in dairy products. They indicated that staphylococcus was the dominant species from the stage of raw milk up to cheese formation. Mounier et al. (2009) identified microbial populations on the surface of the Livarot cheese for used SSCP method.

\section{Fluorescence in Situ Hybridization (FISH)}

FISH method is a non-PCR based molecular technique in which the identification of cells is realized by marking rRNA as a target with probes. This fast and highly sensitive technique is used in microbiology in phylogenetic, ecological and diagnostic identification (Moter and Göbel, 2000; Amann et al., 2001). In their study, Ercolini et al. (2003) used FISH method during the 
ripening period of the Stilton cheese in order to identify the microbial composition thereof.

FISH method has been used in the identification and the counting of lactic acid bacteria (Friedrich and Lenke 2006) and Leuconostoc population (Olsen et al., 2007) in mesophilic dairy starter cultures. Vlkova et al. (2004) used FISH method in identification, counting and isolation of Bifidobacteria in 6 different dairy products and stated that many Bifidobacteria species used in food products might be animal sourced.

Pyrosequencing as a Next Generation Sequencing (NGS)

NGS technologies is possible to determine how many reads of different operational taxonomic units (OTUs) occur in a template. Besides NGS have an estimation of the percent of occurrence of different OTUs in a specific ecosystem. The pyrosequencing method in next generation sequencing methods is based on a real-time quantitative detection of pyrophosphate sequencing technique. In this method is reproduced a solution of the oil in water droplets in the DNA by PCR. DNA singlecoated bead, a single primary mold is attached to each droplet, and then constitutes a clonal colony. Sequencing device has a large number picoliter-volume wells and sequencing enzymes, each of which contains a single bead. Pyrosequencing technique is used and luciferase enzyme added to the DNA of light produced by growing each nucleotide is determined. Combining the series of data is read. Pyrosequencing technology, ultra-high volumes of roughly 400-600 per megabase of DNA in a study by 1.000 .000 by reading ability has great advantages. In recent years, this method is used to identify microbial communities the various ecosystems of soil, fermented foods and cheese, made with descriptions of microbial diversity studies.

Pyrosequencing method has been used in the identification of lactic acid bacteria to study in pearl millet slurries (Humblot and Guyot, 2009), different kinds of cheese (Masoud et al., 2011; Alegría et al., 2012; Quigley et al., 2012; Ercolini et al., 2012), in Brazilian kefir grains (Leite et al., 2012).

\section{Results and Discussion}

Identification of microbial flora should enable the development of a detailed knowledge of microbial ecology. This knowledge is essential to derive scientifically valid or to monitor important LAB in dairy products. Many bacteria do not rely on cultivation, because they had been overgrown with the dominant microbiota, or because they had been defined as viable but not culturable (VBNC), considered as a survival strategy and response to adverse environmental conditions. A DNA-based technique would allow a better understanding on the composition of the LAB flora.

All these studies showed that diagnoses which are put in genetic level will be tested on more and more microorganisms and become standardized. Comparison of molecular fingerprints allows for the analysis of proximity and distance, especially investigation of spread of micro-organisms in a certain area becomes easier. When there is not an ideal typing method, in strains where the population is formed by any of the typing methods, the effectiveness level of the used method should be verified by an independent typing method. This situation is important in the investigation of species displaying especially mini evolutions or substrain shuffling.

Many of the genotype techniques can detect differences in the species and strains of LAB. The biggest advantage of these DNA based methods is that they are universally applicable and that they are bound up with the principle of distinctive feature. General problem with all the techniques, with a population of predominantly relates to the impossibility of detecting microorganisms in a low number of complex ecosystems. Overcome this limitation $10^{3} \mathrm{cfu} / \mathrm{ml}$ or $\mathrm{g}$ detection has the DGGE method. DGGE of all techniques, dealing with LAB identification in dairy products that represent the best in this context for a large amount of technical and comprehensive information available.

Recent advances in next-generation sequencing (NGS) metagenomics analysis capabilities and has a great advantage over DGGE. This method is capable of producing hundreds of gigabases of data in a single sequencing run with the latest instruments and enables rapid sequencing of large stretches of DNA base pairs spanning entire genomes. The expected that this new technology will enable detailed data on the microbial ecology and provides a definition of the role and impact of specific microorganisms in dairy products

\section{References}

Albenzio M, Corbo MR, Rehman SU, Fox PF, De Angelis M, Corsetti A, Sevi A, Gobbetti M. 2001. Microbiological and biochemical characteristics of Canestrato Pugliese cheese made from rawmilk, pasteurized milk or by heating the curd in hot whey. International Journal of Food Microbiology. 67:35-48.

Alegría A, Szczesny P, Mayo B, Bardowski J, Kowalczyk M. 2012. Biodiversity in Oscypek, a traditional Polish cheese, determined by culture-dependent and-independent approaches. Applied and Environmetal Microbiology. 78:1890-1898.

Amann RI, Ludwig W, Schleifer KH. 1995. Phylogenetic identification and in situ detection of individual microbial cells without cultivation. Microbiology. Reviews. 59:143169.

Amann R, Fuchs BM, Behrens S. 2001. The identification of microorganisms by fluorescence in situ hybridization. Current Opinion Biotechnology. 12:231-236.

Ampe F, Ben Omar N, Moizan C, Wacher C, Guyot JP. 1999. Polyphasic study of the spatial distribution of microorganisms in Mexican pozol, a fermented maize dough, demonstrates the need for cultivation-independent methods to investigate traditional fermentations. Applied and Environmental Microbiology. 65:5464-5473.

Ampe F, Miambi E. 2000. Cluster analysis, richness and biodiversity indexes derived from denaturing gradyan gel electrophoresis fingerprints of bacterial communities demonstrates that traditional maize fermentations are driven by the transformation process. International Journal of Food Microbiology. 60:91-97.

Baruzzi F, Morea M, Matarante A, Cocconcelli PS. 2000. Changes in the Lactobacillus community during Ricotta Forte cheese natural fermentation. Journal of Applied Microbiology. 89:807-814. 
ben Omar N, Ampe F. 2000. Microbial community dynamics during production of the Mexican fermented maize dough pozol. Applied and Environmental Microbiology. 66:36643673.

Bouton Y, Guyot P, Beuvir E, Tailliez P, Grappin R. 2002. Use of PCR based method and PFGE for typing and monitoring homofermentative lactobacilli during Comtè cheese ripening. International Journal of Food Microbiology. 76:2738.

Böttger EC. 1989. Rapid determination of bacterial ribosomal RNA sequences by direct sequencing of enzymatically amplified DNA. FEMS Microbiology Letter. 53:171-176.

Callon C, Millet L, Montel MC. 2004. Diversity of lactic acid bacteria isolated from AOC Salers cheese. Journal of Dairy Research. 71:231-44.

Cocconcelli PS, Parisi MG, Senini L, Bottazzi V. 1997. Use of RAPD and 16S rDNA sequencing for the study of Lactobacillus population dynamics in natural whey culture. Letters in Applied Microbiology. 25:8-12.

Cocolin L, Rantsiou K, Iacumin L, Urso R, Cantoni C, Comi G. 2004. Study of the ecology of fresh sausages and characterization of populations of lactic acid bacteria by molecular methods. Applied and Environmental Microbiology. 70:1883-1894.

Coppola S, Blaiotta G, Ercolini D, Moschetti G. 2001. Molecular evaluation of microbial diversity occurring in different types of Mozzarella cheese. Journal of Applied Microbiology. 90:414-420.

Corroler D, Magin I, Desmasures N, Guèguen M. 1998. An ecological study of lactococci isolated from raw milk in the Camembert cheese registered designation of origin area. Applied Environmental Microbiology. 64:4729-4735.

Dasen A, Berthier F, Grappin R, Williams AG, Banks J. 2003. Genotypic and phenotypic characterization of the dynamics of the lactic acid bacterial population of adjunct-containing Cheddar cheese manufactured from raw and microfiltered pasteurised milk. Journal of Applied Microbiology. 94:595607.

De Candia S, De Angelis M, Dunlea E, Minervini F, McSweeney PLH, Faccia M, Gobbetti M. 2007. Molecular identification and typing of natural whey starter cultures and microbiological properties of related traditional Mozzarella cheeses. International. Journal of Food Microbiology. 119:182-191.

Delbes C, Montel MC. 2005. Design and application of a Staphylococcus specific Single Strand Conformation Polymophism-PCR analysis to monitor Staphylococcus population diversity and dynamics during production of raw milk cheese. Letters in Applied Microbiology. 41:169-174.

Dellaglio F, Felis GE, Castioni A, Torriani S, Germond JE. 2005. Lactobacillus delbrueckii subsp. indicus subsp. nov., isolated from Indian dairy products. International Journal of Systematic and Evolutionary Microbiology. 55:401-4.

Desmasures N, Mangin I, Corroler D, Guèguen M. 1998. Characterization of lactococci isolated from milk produced in the Camembert region of Normandy. Journal of Applied Microbiology . 85:999-1005.

Dolci P, Alessandria V, Zeppa G, Rantsiou K, Cocolin L. 2008a. Microbiological characterization of artisanal Raschera PDO cheese: analysis of its indigenous lactic acid bacteria. Food Microbiology. 25:392-399.

Duineveld BM, Rosado AS, van Elsas JD, van Veen JA. 1998. Analysis of the dynamics of bacterial communities in the rhizosphere of chrysanthemum via denaturing gradyan gel electrophoresis and substrate utilization patterns. Applied and Environmental Microbiology. 64:4950-4957.

Duthoit F, Godon JJ, Montel MC. 2003. Bacterial community dynamics during production of registered designation of origin salers cheese as evaluated by $16 \mathrm{~S}$ rRNA gene singlestrand conformation polymorphism analysis. Applied and Environmental Microbiology. 69:3840-3848.
El-Baradei G, Delacroix-Buchet A, Ogier JC. 2007. Biodiversity of Bacterial Ecosystems in Traditional Egyptian Domiati Cheese. Applied and Environmental Microbiology. 73: 1248-1255.

Ercolini D, Hill PJ, Dodd ERC. 2003. Bacterial community structure and location in stilton cheese. Applied and Environmental Microbiology. 69:3540-3548.

Ercolini D, De Filippis F, La Storia A, Iacono M. 2012. A "remake" of the microbiota involved in the production of water buffalo mozzarella cheese by high throughput sequencing. Applied and Environmental Microbiology. 78:8142-8145.

Flórez, A.B. and Mayo, B. 2006. PCR-DGGE as a tool for characterizing dominant microbial populations in the Spanish blue--veined Cabrales cheese. International Dairy Journal 16: 1205-1210.

Fasoli S, Marzotto M, Rizzotti L, Rossi F, Dellaglio F, Torriani, S. 2003. Bacterial composition of commercial probiotic products as evaluated by PCR-DGJE analysis, International Journal of Food Microbiology. 82:59-70.

Fortina MG, Ricci G, Acquati A, Zeppa, G, Gandini A, Manichini PL. 2003. Genetic characterization of some lactic acid bacteria occurring in an artisanal protected denomination origin (PDO) Italian cheese, the Toma piemontese. Food Microbiology. 20:397-404.

Foschino R, Nucera D, Volponi G, Picozzi C, Ortoffi M, Bottero MT. 2008. Comparison of Lactococcus garvieae strains isolated in northern Italy from dairy products and fishes through molecular typing. Journal of Applied Microbiology . 105:652-662.

Friedrich U, Lenke J. 2006. Improved enumeration of lactic acid bacteria in mesophilic dairy starter cultures by using multiplex quantitative real-time PCR and flow cytometryfluorescence in situ hybridization. Applied and Environmental Microbiology. 72:4163-4171.

Gevers D, Huys G, Swings J. 2001. Applicability of rep-PCR fingerprinting for differentiation of Lactobacillus species. FEMS Microbiology Letter. 205:31-36.

Giraffa G, Neviani E. 2000. Molecular identification and characterisation of food-associated lactobacilli. Italian Journal of Food Science. 4:403-423.

Giraffa G, Lazzi C, Gatti M, Rossetti L, Mora D, Neviani E. 2003. Molecular typing of Lactobacillus delbrueckii of dairy origin by PCR-RFLP of protein coding genes, International Journal of Food Microbiology. 82:163-172.

Giovannoni SJ, Britschgi TB, Moyer CL, Field KG. 1990. Genetic diversity in Sargasso Sea bacterioplankton. Nature (London) 345:60-63.

Harmsen, D, Karch H. 2004. How close is close enough? Not the tree of live but a living tree is of major importance for 16S rDNA based microbial species identification. American Society of Microbiology News. 70:19-24.

Head IM, Saunders JR, Pickup RW. 1998. Microbial evolution, diversity, and ecology, a decade of ribosomal analysis of uncultivated microorganisms. Microbiology Ecology. 35:121.

Heilig GHJ, Zoetendal EG, Vaughan EE, Marteau P, Akkermans ADL, de Vos WM. 2002. Molecular diversity of Lactobacillus spp., and other lactic acid bacteria in the human intestine as determined by specific amplification of 16S ribosomal DNA. Applied and Environmental Microbiology. 68:114-123.

Holzapfel WH, Haberer P, Geisen R, Bjorkroth J, Schillinger U. 2001. Taxonomy and important features of probiotic microorganisms in food and nutrition. American Journal of Clinical Nutrition. 73:365-373.

Humblot C, Guyot JP. 2009. Pyrosequencing of tagged 16S rRNA gene amplicons for rapid deciphering of the microbiomes of fermented foods such as pearl millet slurries. Applied and Environmental Microbiology. 75:4354-4361. 
Janssen P, Coopman R, Huys G, Swings J, Bleeker M, Vos P, Zabeau M, Kersters K. 1996. Evaluation of the DNA fingerprinting method AFLP as a new tool in bacterial taxonomy. Journal of General Microbiology. 142:18811893.

Leite AMO, Mayo B, Rachid CTCC, Peixoto RS, Silva JT, Paschoalin VMF, Delgado S, 2012. Assessment of the microbial diversity of Brazilian kefir grains by PCR-DGGE and pyrosequencing analysis. Food Microbiology. 31:215221.

Lortal S, Rouault A, Guezenec S, Gautier M. 1997. Lactobacillus helviticus: Strain typing and genomic size estimation by pulsed field gel electrophoresis. Current of Microbiology. 34:180-5.

Ludwig W, Schleifer KH. 1994. Bacterial phylogeny based on $16 \mathrm{~S}$ and 23S rRNA sequence analysis. FEMS Microbiology Reviewers. 15:155-173.

Masoud W, Takamiya M, Vogensen FK, Lillevang S, Al-Soud WA, Sørensen SJ, Jakobsen M. 2011. Characterization of bacterial populations in Danish raw milk cheese made with different starter cultures by denaturing gradient gel electrophoresis and pyrosequencing. International Dairy Journal. 21:142-148.

McCartney AL. 2002. Application of molecular biological methods for studying probiotics and the gut flora, British Journal of Nutrition. 88:29-S37.

Mohammed M, Abd El-Aziz H, Omran N, Anwar S, Awad S, El-Soda M. 2009. Rep-PCR characterization and biochemical selection of lactic acid bacteria isolated from the Delta area of Egypt. International Journal of Food Microbiology. 128:417-423.

Morea M, Baruzzi F, Cappa F, Cocconcelli PS. 1998. Molecular characterization of the Lactobacillus community in traditional processing of mozzarella cheese. International Journal of Food Microbiology .43:53-60.

Morea M, Baruzzi F, Cocconcelli PS. 1999. Molecular and physiological characterization of dominant bacterial populations in traditional mozzarella cheese processing. Journal of Applied Microbiology. 87:574-582.

Moschetti G, Blaiotta G, Aponte M, Catzeddu P, Villani F, Deiana P, Coppola S. 1998. Random amplified polymorphic DNA and amplified ribosomal DNA spacer polymorphism: powerful methods to differentiate Streptococcus thermophilus strains. Journal of Applied Microbiology. 85: 25-36.

Moter A, Göbel UB. 2000. Fluorescence in situ hybridization (FISH) for direct visualization of microorganisms. Journal of Microbiology Methods. 41:85-112.

Mounier J, Monnet C, Jacques N, Antoinette A, Irlinger F. 2009. Assessment of the microbial diversity at the surface of Livarot cheese using culture-dependent and independent approaches. International Journal of Food Microbiology. 133:31-7.

Mullis KB. 1990. "The unusual origin of the polymerase chain reaction". Scientific American. 262(4): 56-61, 64-5.

Muyzer G, De Waal EC, Uitterlinden AG. 1993. Profiling of complex microbial populations by denaturing gradyan gel electrophoresis analysis of polymerase chain reactionamplified genes coding for $16 \mathrm{~S}$ rRNA. Applied and Environmental Microbiology. 59:695-700.

Ogier JC, Son O, Gruss A, Tailliez P, Delacroix-Buchet A. 2002. Identification of the bacterial microflora in dairy products by temporal temperature gradient gel electrophoresis. Applied and Environmental Microbiology. 68:3691-3701.

Olive DM, Bean P. 1999. Principles and applications of methods for DNA-based typing of microbal organisms. Journal of Clinical Microbiology. 37:1661-1669.
Olsen KN, Brockmann E, Molin S. 2007. Quantification of Leuconostoc populations in mixed dairy starter cultures using fluorescence in situ hybridization. Journal of Applied Microbiology. 103:855-863.

Oneca M, Irigoyen A, Ortigosa M, Torre P. 2003. PCR and RAPD identification of $L$. plantarum strains isolated from ovine milk and cheese. Geographical distribution of strains. FEMS Microbiology Letter. 227:271-277.

Quigley L, O'Sullivan O, Beresford TP, Ross RP, Fitzgerald GF, Cotter PD. 2012. High-throughput sequencing for detection of subpopulations of bacteria not previously associated with artisanal cheese. Applied and Environmental Microbiology. 78:5717-5723.

Rigottier-Gois L, Le Bourhis AG, Gramet G, Rochet V, Doré J. 2003. Fluorescent hybridisation combined with flow cytometry and hybridisation of total RNA to analyse the composition of microbial communities in human faeces using 16S rRNA probes. FEMS Microbiology Ecology. 43:237-245.

Rossetti L, Giraffa G. 2005. Rapid identification of dairy lactic acid bacteria by M13-generated, RAPD-PCR fingerprint databases. Journal of Microbiological Methods. 63:135-144.

Roy D, Ward P, Champagne G. 1996. Differentiation of bifidobacteria by use of pulsed-field gel electrophoresis and polymerase chain reaction. International Journal of Food Microbiology. 29:11-29.

Roy D, Ward P, Vincent D, Mondou F. 2000. Molecular identification of potentially probiotic lactobacilli. Current Microbiology. 40:40-46.

Saarela M, Mogensen G, Fonden R, Matto J, Mattila-Sandholm T. 2000. Probiotic bacteria: safety, functional and technological properties. Journal of Biotechnology. 84:197215.

Sánchez I, Seseña S, Poveda JM, Cabezas L, Palop L. 2006. Genetic diversity, dynamics and activity of Lactobacillus community involved in traditional processing of artisanal Manchego cheese. International Journal of Food Microbiology. 107:265-273.

Temmerman R, Huys G, Swings J. 2004. Identification of lactic acid bacteria, culture-dependent and culture independent methods. Trends in Food Science \& Technology. 15:348359.

Tynkkynen S, Satokari R, Saarela M, Mattila-Sandholm T, Saxelin M. 1999. Comparison of ribotyping, randomly amplified polymorphic DNA Analysis, and pulsed-field gel electrophoresis in typing of Lactobacillus rhamnosus and $L$. casei strains. Applied Environmental Microbiology. 65:3908-14.

Walter J, Hertel C, Tannock GW, Lis CM, Munro K. 2001. Hammes W.P., Detection of Lactobacillus, Pediococcus, Leuconostoc, and Weissella species in human feces by using group-specific PCR primers and denaturing gradyan gel electrophoresis. Applied and Environmental Microbiology. 67:2578-2585.

Ward DM, Weller R, Bateson MM. 1990. 16S rRNA sequences reveal numerous uncultured microorganisms in a natural community. Nature. 345:63-65.

Ventura M, Zink R. 2002. Specific identification and molecular typing analysis of Lactobacillus johnsonii by using PCRbased methods and pulsed-field gel electrophoresis. FEMS Microbiology Letter. 217:141-54.

Vlkova E, Rada V, Trojanova I. 2004. Enumeration, Isolation and Identification of Bifidobacteria from dairy products. Acta Agriculturae Slovenica. 84:31-36. 